\title{
Farmácia Popular Program: pharmaceutical market analysis of antihypertensive acting on the renin-angiotensin system medicines
}

\author{
Programa Farmácia Popular: análise do mercado farmacêutico \\ de anti-hipertensivos do sistema renina-angiotensina
}

Rondineli Mendes da Silva ${ }^{1}$

Gabriela Costa Chaves ${ }^{1}$

Luisa Arueira Chaves ${ }^{2}$

Mônica Rodrigues Campos ${ }^{1}$

Vera Lucia Luiza ${ }^{1}$

Andréa Dâmaso Bertoldi ${ }^{3}$

Dennis Ross-Degnan ${ }^{4}$

Isabel Cristina Martins Emmerick ${ }^{4}$

\footnotetext{
${ }^{1}$ Departamento de Política de Medicamentos e Assistência Farmacêutica, Escola Nacional de Saúde Pública Sergio Arouca, Fiocruz. R. Leopoldo Bulhões 1480, Manguinhos. 21041-210 Rio de Janeiro RJ Brasil. rondineli.mendes@ gmail.com

${ }^{2}$ Faculdade de Farmácia, Universidade Federal do Rio de Janeiro. Macaé RJ Brasil. ${ }^{3}$ Departamento de Medicina Social, Faculdade de Medicina. Universidade Federal de Pelotas. Pelotas share was analysed by therapeutic sub-classes and by individual company. Losartan as a single product accounted for the highest market share among angiotensin II antagonists. National companies had higher sales volume during the study period, while multinational companies had higher sales value. Changes in pharmaceutical market share coincided with the inclusion of specific products in the list of medicines covered by FP and with in creases in or exemption from patient copayment. Key words Pharmaceutical trade, Antihypertensive agents, Interrupted time series analysis, Pharmaceutical services, Government programs
} RS Brasil.

${ }^{4}$ Department of Population Medicine, Harvard Pilgrim Health Care Institute and Harvard Medical School. Boston MA United States of America.

\begin{abstract}
This paper aims to analyse changes in the retail pharmaceutical market following policy changes in the Farmácia Popular Program (FP), a medicines subsidy program in Brazil. The retrospective longitudinal analyses focus on therapeutic class of agents acting on the renin-angiotensin system. Data obtained from QuintilesIMS (formerly IMS Health) included private retail pharmacy sales volume (pharmaceutical units) and sales values from 2002 to 2013. Analyses evaluated changes in market share following key FP policy changes. The therapeutic class was selected due to its relevance to hypertension treatment. Market
\end{abstract}

Resumo Este artigo visa analisar as mudanças no mercado de varejo farmacêutico, seguindo as alterações de diretiva no Programa Farmácia Popular (FP), que realiza subvenção de medicamentos no Brasil, em parceria pública privada. Foi realizada análise longitudinal retrospectiva dos medicamentos da classe terapêutica dos agentes que atuam sobre o sistema renina-angiotensina. Os dados obtidos do QuintilesIMS incluíram o varejo farmacêutico em termos do volume e valores de vendas de 2002 a 2013. Análises realizadas consideraram intervenções e reformas ocorridas no FP e seu impacto no mercado farmacêutico da classe terapêutica selecionada, devido a sua relevância para o tratamento da hipertensão. Também se examinou o comportamento do mercado tomando por base as empresas farmacêuticas produtoras. Losartan monodroga representou a maior fatia de mercado entre os antagonistas de angiotensina II. Empresas nacionais obtiveram maior volume de vendas durante o período de estudo, enquanto as empresas multinacionais exibiram maior valor de vendas. Mudanças no mercado farmacêutico coincidiram com a inclusão de produtos específicos na lista de medicamentos abrangidos pelo FP e com aumentos ou isenção de copagamento pelos pacientes.

Palavras-chave Comercialização de medicamentos, Anti-hipertensivos, Análise de séries temporais interrompida, Assistência farmacêutica, Programas governamentais 


\section{Introduction}

The Brazilian retail pharmaceutical market has increased significantly since 2003 (US\$ 4.85 billion), reaching US $\$ 26.9$ billion in sales in $2013^{1}$. The last National Health Accounts 2010-2013 shows that total expenditure on medicines were $1.6 \%$ of Brazil's gross domestic product ${ }^{2}$ (GDP) on average in 2013, what is slightly higher than Organization for Economic Co-operation and Development (OECD) countries $(1.4 \%)^{3}$. National expenditure on medicines accounted for more than $20 \%$ in the final goods and health services expenditure in the same year'.

According to OECD, the growing demand for medicines and the introduction of new products on the market are the main sources of the growth of expenditure on medicines, being emphasized that the drug consumption continues to increase ${ }^{3}$.

Spending on medicines in Brazil was disproportionately from household rather than government budgets; in the four-year period, medicines accounted for 279.4 billion reais in household spending compared with 31.3 billion reais in government spending, a 9-fold difference ${ }^{2}$. Access to health care is a constitutional right in Brazil, including access to medicines, and until 2004 medicines were provided free of charge in public health care facilities. In May 2004, Brazil's government announced a new additional mechanism to improve the Brazilian population's access to medicines. Farmácia Popular Program (FP) was part of President Lula's working plan for his first mandate. This policy consisted in a list of medicines to be subsided by the government and provided in public and private pharmacies. FP was especially aimed at low-income people covered by private health care insurance, as in Brazil few of them include outpatient medicines as a benefit. It also targeted medicines used to treat the most prevalent diseases in outpatient care ${ }^{4}$.

Machado et al..$^{5}$ pointed out the Farmácia Popular Program as one of the four most important health policies in Brazil. It was innovative for two main reasons. Firstly, it introduced provision of medicines with patient copayments. Second, it established government partnerships with private retail pharmacies, which was responsible for its widespread expansion.

FP started in public facilities and in 2006 the Ministry of Health (MoH) expanded the program to include the private sector. In December 2009, administrative changes were implemented and this expansion was called "Aqui Tem Farmá- cia Popular" (AFP). At this point the list contained medicines for hypertension, diabetes and contraception. In 2010, this list was broadened to include medicines for rhinitis, asthma, Parkinson disease, osteoporosis, glaucoma, dyslipidemia, adult diapers and one more anti-hypertensive (losartan) ${ }^{6}$. Finally, in 2011, under the name "Health Has No Price" (Saúde Não Tem Preço SNP), all medicines for hypertension and diabetes were $100 \%$ subsidized. In 2012, antiasthma medicines were also exempted from user copayment.

The MOH defines specific medicine prices for each product, standardized for the whole country. A reference price (RP) for each medicine is established based on the maximum retail price list as defined by Drug Market Regulation Chamber of National Health Surveillance Agency (CMED/Anvisa). RP is the average of the prices of the least expensive medicines (accounting for $25 \%$ of the market) weighted by their market share. By July 2006, besides the RP, the concept of selling price was introduced. That means that if the selling price is higher than the RP, the patient is responsible for paying $10 \%$ of the RP plus the difference between the RP and the selling price. If the retail price of the product is lower than the $\mathrm{RP}$, the government will only pay $90 \%$ of this retail price; otherwise the government pays $90 \%$ of RP.

To be able being accredited for the FP Program, private pharmacies must prove they are complying with health and commercial regulations, which includes marketing authorization by ANVISA, labour regulation, having a pharmacist in charge, capacity to issue electronic invoices and receipts, web connection and staff trained to conduct properly FP rules and procedures. All dispensations are processed online in real time.

In this sense is expected that the changes in the Farmácia Popular Program could cause impact in the Brazilian pharmaceutical market. Thus, the selection of medicines acting on the renin-angiotensin system occurred due to the magnitude of the use of this group of medicines in Brazil and within the $\mathrm{FP}^{7}$. The treatment of hypertension is a priority in Brazil, being covered by the program since it affects 1 in every 4 Brazilians 18 years and older, and chronic diseases have a significant weight in the country's morbidity and mortality profile ${ }^{8}$.

Since this program relies on a partnership with the private retail market, we sought to investigate if the $\mathrm{FP}$ affected the market dynamics of the selected therapeutic class by changing the 
This study is part of a broader Project called "Farmácia Popular: the impact of subsidy policies in access and use of medicines in Brazil" (ISAUM-Br), that aimed to describe and evaluate the impact on access to medicines of the governmental medicines subsidy policies implemented between 2002 and 2012 using a longitudinal approach $^{9}$. The ISAUM-Br project was approved by the World Health Organization Research Ethics Review Committee under the protocol identification number RPC554 and the Brazilian National Ethical Committee.

\section{Interventions}

This is a retrospective longitudinal study examining changes in market share during the four phases of FP: (i) FP-Gov - the implementation of the program by the government in May 2004 in government-owned facilities; (ii) AFP-I the expansion of the program with the inclusion of the private sector in March 2006; (iii) AFP-II - the reduction of reference prices for most medicines by an average of $24.5 \%$ in April 2009; and (iv) SNP - the implementation of covered medicines for hypertension and diabetes free of charge to patients in February 2011.

Antihypertensive medicines dispensed for free during SNP were: (i) beta-blocking agents: atenolol $25 \mathrm{mg}$ and propranolol hydrochloride $40 \mathrm{mg}$; (ii) diuretics: hydrochlorothiazide 25 $\mathrm{mg}$; and (iii) agents acting on the renin-angiotensin system inhibitors (Class C09 on European Pharmaceutical Marketing Research Association (EphMRA) Anatomical Classification) including (a) the angiotensin-converting-enzyme (ACE) inhibitors captopril $25 \mathrm{mg}$ and enalapril maleate $10 \mathrm{mg}$; and (b) the angiotensin II antagonist or angiotensin receptor blocker (ARB) losartan potassium $50 \mathrm{mg}^{10}$.

\section{Data sources and study population}

QuintilesIMS (formerly IMS Health) was the source of data on volume (pharmaceutical units) and sales (in Brazilian currency - reais, $\mathrm{R} \$$ ) in

retail private pharmacies in Brazil from January 2002 to October 2013. The data provided by QuintilesIMS covers $100 \%$ of the Brazilian pharmaceutical market, is weighted, consistent and has internal validity for the analyzed period. The C09 group was selected due its relevance in the hypertension treatment, its high consumption and impact on total FP expenditure ${ }^{7}$.

\section{Analysis}

The analysis is divided in three parts. The first is a descriptive analysis of market share based on sales volume; the second, an interrupted time series (ITS) of the market share for ACEs (captopril, enalapril) and ARB (losartan) and medicines not covered (MNC) by FP; and the third comprises an analysis of the top eight manufacturers' market share, based on volume (pharmaceutical units) and sales (in Brazilian reais) of C09 EphMRA class in each phase of FP, from January 2002 to October 2013. Manufacturers were characterized by whether they were generic producers.

The description on the percentage distribution of market share in volume (pharmaceutical units) was based on ACEs and ARBs, as combinations and single drugs. Chart 1 presents the codes, therapeutic class/sub-classes, and medications from the Brazilian Pharmaceutical included in the EphMRA 2013 classification of $\mathrm{C} 9^{11}$. All of them were addressed in this study.

Additionally, we calculated the affordability of one representative ACE and ARB medication. Affordability was calculated using the most recent values. We considered the official national minimum wage $(880,00$ reais), the maximum selling price established by Anvisa, the lowest value added tax (VAT) of $12 \%$, and the reference price defined by FP. We considered the recommended dose in the most recent Hypertension Treatment Guideline: 1 tablet 50mg for losartan and 2 tablets $10 \mathrm{mg}$ to enalapril daily.

\section{Statistic methods}

In the second part of the analysis, we used interrupted time series (ITS) segmented linear regression models of the monthly market share for captopril, enalapril, losartan and MNC. In estimating effects, ITS models adjust for pre-existing trends in the period before the policy change ${ }^{12,13}$. Segmented linear regression models were build using the prais command in STATA v12.

In preliminary analyses, the models include all four policy periods described previously; the 
Chart 1. Code, Therapeutic Class/sub-classes according European Pharmaceutical Marketing Research Association C09 medicines Anatomical Classification, Brazil, 2013.

\begin{tabular}{|c|c|c|}
\hline Code & Therapeutic Class/sub-classes & Medicines description \\
\hline \multicolumn{3}{|c|}{ C09-Agents acting on the renin-angiotensin system } \\
\hline C09A0 & ACE inhibitors, single & $\begin{array}{l}\text { Benazepril, Captopril }{ }^{\star} \text {, Cilazapril, Delapril, Enalapril }{ }^{\star} \text {, } \\
\text { Enalaprilat, Fosinopril, Lisinopril, Perindopril, Quinapril, } \\
\text { Ramipril, Trandolapril }\end{array}$ \\
\hline C09B1 & $\begin{array}{l}\text { ACE inhibitor fixed-dose combination } \\
\text { with antihypertensive (C2) and/or } \\
\text { diuretics (C3) }\end{array}$ & $\begin{array}{l}\text { Benazepril+Hydrochlorothiazide, } \\
\text { Captopril+Hydrochlorothiazide, } \\
\text { Cilazapril+Hydrochlorothiazide, } \\
\text { Enalapril+Hydrochlorothiazide, } \\
\text { Fosinopril+Hydrochlorothiazide, } \\
\text { Lisinopril+Hydrochlorothiazide, Perindopril+Indapamide, } \\
\text { Ramipril+Hydrochlorothiazide }\end{array}$ \\
\hline C09B3 & $\begin{array}{l}\text { ACE inhibitor fixed-dose combination } \\
\text { with calcium antagonists (C8) }\end{array}$ & $\begin{array}{l}\text { Benazepril+Amlodipine, Delapril+Manidipine, } \\
\text { Enalapril+Amlodipine, Ramipril+Amlodipine }\end{array}$ \\
\hline $\mathrm{C} 09 \mathrm{C} 0$ & Angiotensin II antagonists, single & $\begin{array}{l}\text { Candesartan Cilexetil, Irbesartan, Losartan } \\
\text { Olmesartan Medoxomil, Telmisartan, Valsartan, }\end{array}$ \\
\hline C09D1 & $\begin{array}{l}\text { Angiotensin II antagonist fixed-dose } \\
\text { combination with antihypertensive } \\
\text { (C2) and/or diuretics }\end{array}$ & $\begin{array}{l}\text { Candesartan Cilexetil+Hydrochlorothiazide, } \\
\text { Irbesartan+Hydrochlorothiazide, } \\
\text { Losartan+Hydrochlorothiazide, Olmesartan } \\
\text { Medoxomil+Hydrochlorothiazide, } \\
\text { Telmisartan+Hydrochlorothiazide, } \\
\text { Valsartan+Hydrochlorothiazide }\end{array}$ \\
\hline C09D3 & $\begin{array}{l}\text { Angiotensin II antagonist fixed-dose } \\
\text { combination with calcium antagonists }\end{array}$ & $\begin{array}{l}\text { Candesartan Cilexetil+Felodipine, Losartan+Amlodipine, } \\
\text { Olmesartan Medoxomil+ Amlodipine, } \\
\text { Telmisartan+Amlodipine, Valsartan+Hydrochlorothiazide }\end{array}$ \\
\hline C09X0 & $\begin{array}{l}\text { Other agents acting on the renin } \\
\text { angiotensin system }\end{array}$ & Aliskiren, Amlodipine, Hydrochlorothiazide \\
\hline
\end{tabular}

* medicines in Farmacia Popular list.

inclusion of losartan in FP in 2010 was also modeled as an intervention. The first intervention (beginning of FP) and the inclusion of losartan in the medicine list did not show any effects, so those two interventions were excluded from the final analytical model.

The final ITS models evaluated the impact of AFP-I, AFP-II and SNP, including four segments, with 50, 35, 20 and 31 monthly observations, respectively. The baseline segment was fit with an intercept and a variable estimating trend. Each policy effect was estimated by one variable representing the change in level of the outcome immediately after the policy and a second representing the change in trend of the post-policy segment. All parameters were retained in the models. Results with $\mathrm{p}<0.05$ are highlighted in bold. To create single number summaries of policy effects, we calculated estimates of the relative percentage changes in the outcomes compared to expected values based on prior trends in April 2007, May
2010 and March 2012, about one year after each of the interventions studied.

For the analysis of the top manufacturers' market share, we totaled the sales in volume and value for each product in C09 in each FP intervention period. The status of a manufacturer as national or multinational was based in Kornis et al. ${ }^{14}$; manufacturer status as a generic (non-branded) producer considered the situation in August 2016.

\section{Results}

In terms of volume, there was a decrease in the market share of the sub-class of ACE inhibitors between 2002 and 2006; this decrease can be observed in both single drug products and combinations, although it was more pronounced in the former. In the same period, the ARBs (single drug and combinations) rapidly increased their 
market share, considering the whole C09 market, both covered and not covered by FP (Figure 1).

After 2006, the decrease in market share of ACE inhibitors is not as steep as does the increasing trend for single drug ARBs. After 2010, the market share of ARB single drug products increased and after 2011, the single drug ACE inhibitors are no longer the leading class in relation to single drug ARBs (Figure 1).

The single drug products had the highest percentage of market share during the period analyzed. The combinations increased their share between 2002 and 2006, but their increase was slow compared to the previous period. Their market share maintained constant until 2010, after which it accounted for less than $20 \%$ of the total market (Figure 1).

Analyzing the percentage of market share and the sales volume in pharmaceutical units for the C09 therapeutic class (Figure 2), the medicines covered by the FP (captopril, enalapril and losar$\tan$ ) increased their share in volume throughout the study period. For enalapril and captopril, this increase was mostly after AFP-I and AFP-II, and for Losartan, the increase was after SNP, demonstrating the effect of the FP interventions in the retail pharmaceutical market for this therapeutic class. For medicines not covered by the FP, there were no significant changes related to the FP interventions.

Captopril and enalapril had a decreasing trend in market share in the baseline period, representing $25.2 \%$ and $32.5 \%$ of the market volume, respectively, by February 2006. Losartan had an impressive growth from $2.9 \%$ to $19.1 \%$ in the same period. The medicines not covered in FP had a relatively stable baseline trend (Figure 2 and Table 1).

The implementation of AFP-I, which consisted of the introduction of FP in retail pharmacies, was associated with changes in captopril, enalapril and losartan market share, with decreasing market share of the first two medications and increasing share of the third, which was not part of the FP medicines list at the time. The MNC also experienced a reduction in their market share in this period. In April 2007, the changes in market share were respectively $5.09 \%, 6.97 \%$,

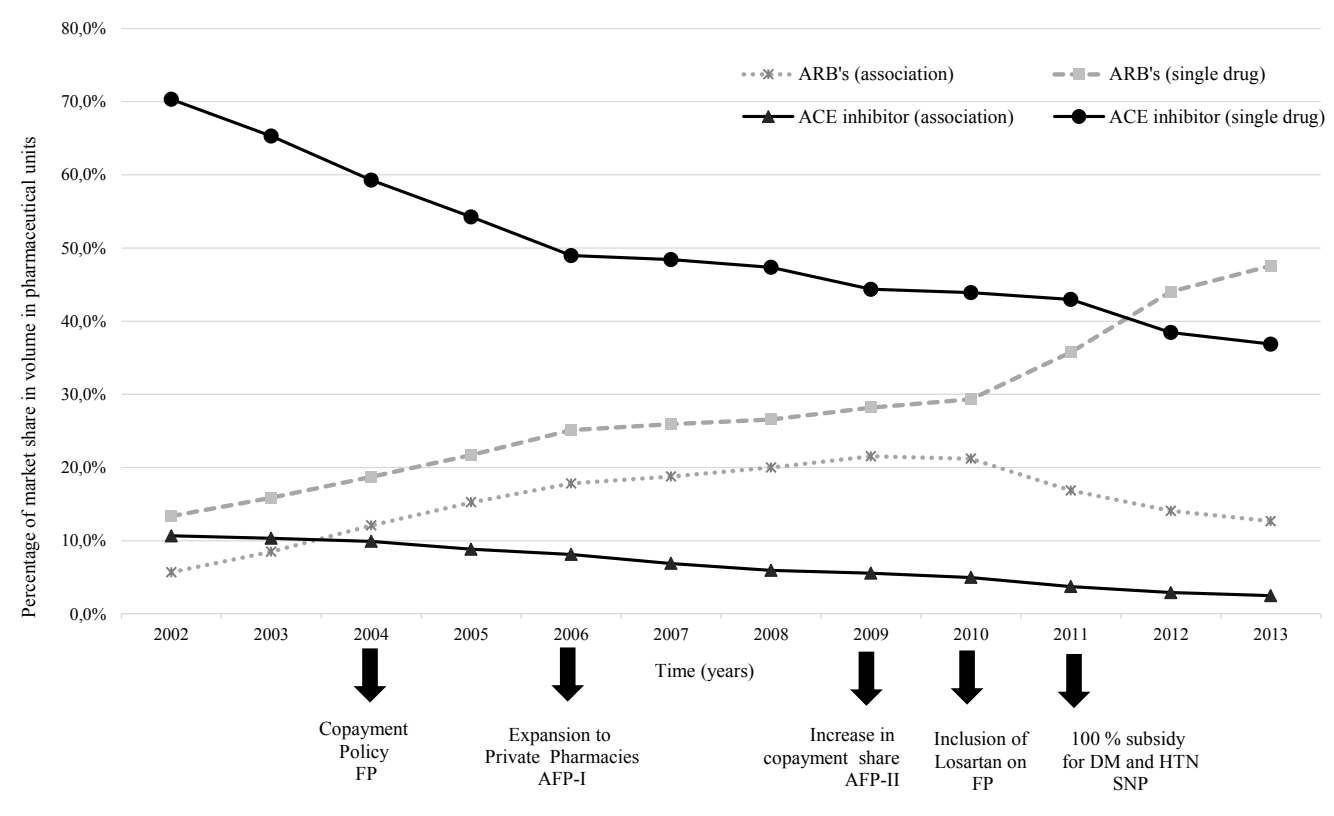

Figure 1. Percentage distribution of market share in volume (pharmaceutical units) of Therapeutic Class C09 sub-class. IMS Health data Brazil, 2002 to 2013.

ACE inhibitor - Angiotensin-converting-enzyme inhibitor. ARB — Angiotensin receptor blockers. ARB's (combination) C09D1 and C09D3 subclasses. ARB's (single drug) - C09C0 subclass. ACE inhibitor (combination) - C09B1 and C09B3 subclass. ACE inhibitor (single drug) - C09A0. 

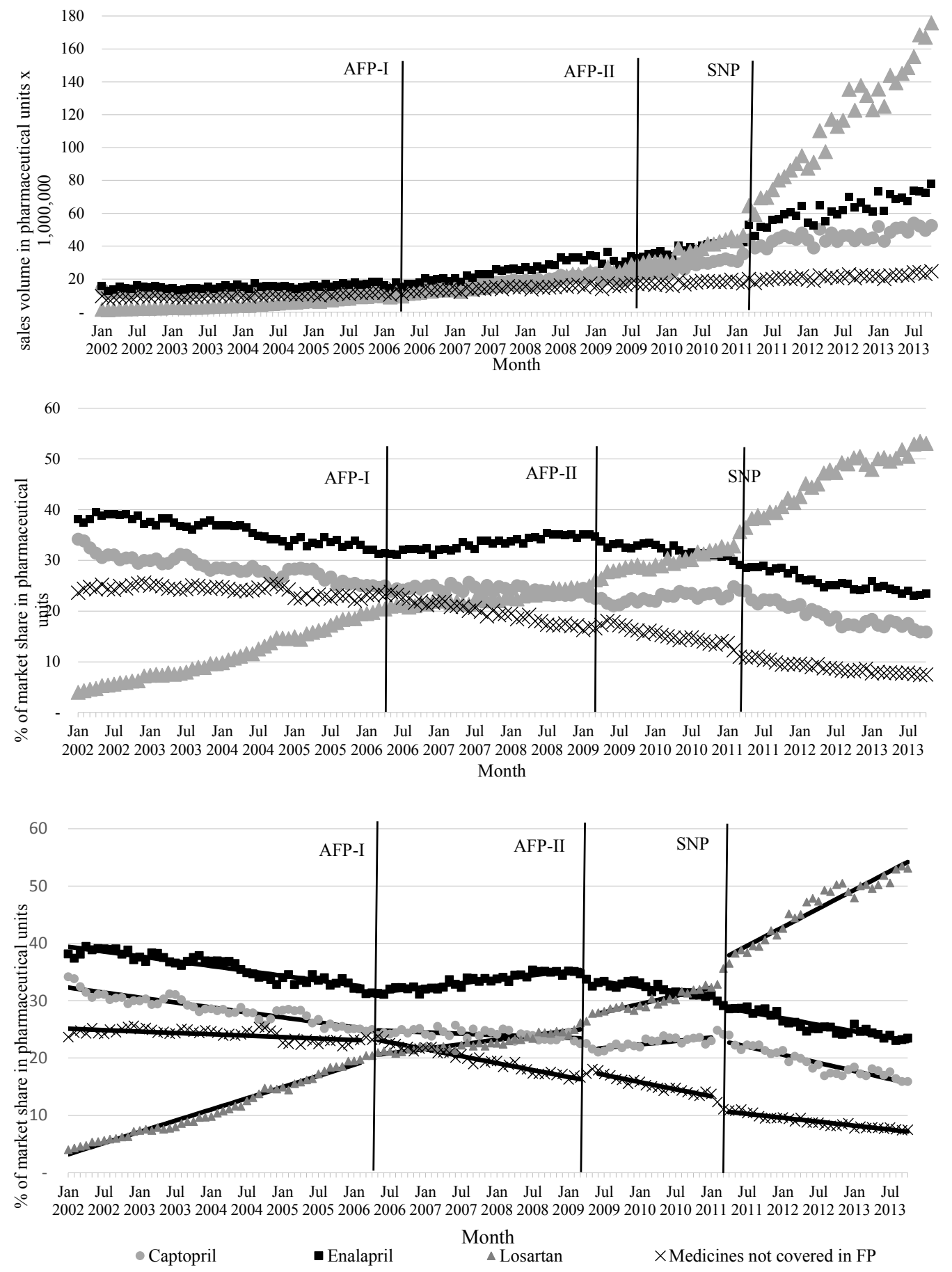

Figure 2. Monthly market share in volume and in sales for C09 therapeutic class from segmented regression models, for captopril, enalapril, losartan and medicines not covered in FP by stage of Farmácia Popular Program, Brazil, 2002 to 2013.

FP-Gov — implementation of the program in public sector; AFP-I — expansion for private sector; AFP-II — reduction of reference prices and consequent increase patient copayment; SNP — all covered medicines for hypertension and diabetes being free of charge to patients. 
Table 1. Baseline level and trend in monthly market share in volume for captopril, enalapril, losartan and medicines not covered in FP and changes in level and trend by stage of the Farmácia Popular Program, Brazil, 2002 to 2013.

\begin{tabular}{|c|c|c|c|c|c|}
\hline & & Captopril & Enalapril & Losartan & $\begin{array}{l}\text { Medicines not } \\
\text { covered in FP }\end{array}$ \\
\hline \multirow[t]{3}{*}{ Baseline } & Level & 32.43 & 39.55 & 2.90 & 25.16 \\
\hline & Trend & -0.14 & -0.14 & 0.33 & -0.04 \\
\hline & Level in Feb-2006 & 25.21 & 32.54 & 19.15 & 23.11 \\
\hline \multirow[t]{4}{*}{$\begin{array}{l}\text { AFP I } \\
(\text { March 2006) }\end{array}$} & $\begin{array}{l}\text { Level AFP I } \\
\text { (Change at the intervention) }\end{array}$ & $\begin{array}{c}-0.06 \\
(-1.2 ; 1.07)\end{array}$ & $\begin{array}{c}-0.94 \\
(-1.87 ;-0.01)\end{array}$ & $\begin{array}{c}0.64 \\
(-0.88 ; 2.15)\end{array}$ & $\begin{array}{c}0.32 \\
(-0.44 ; 1.09)\end{array}$ \\
\hline & Trend AFP II & $\begin{array}{c}0.1 \\
(0.06 ; 0.15)\end{array}$ & $\begin{array}{c}0.26 \\
(0.22 ; 0.3)\end{array}$ & $\begin{array}{c}-0.19 \\
(-0.26 ;-0.13)\end{array}$ & $\begin{array}{c}-0.16 \\
(-0.19 ;-0.13)\end{array}$ \\
\hline & $\begin{array}{l}\% \text { relative change } \\
\text { (April } 2007 \text { - AFP II) }\end{array}$ & 5.09 & 6.97 & -7.14 & -7.12 \\
\hline & Level in Mar-2009 & 23.43 & 35.38 & 25.01 & 16.30 \\
\hline \multirow[t]{4}{*}{$\begin{array}{l}\text { AFP II } \\
\text { (April 2009) }\end{array}$} & $\begin{array}{l}\text { Level AFP II } \\
\text { (Change at the intervention) }\end{array}$ & $\begin{array}{c}-1.8 \\
(-3.22 ;-0.39)\end{array}$ & $\begin{array}{c}-2.08 \\
(-3.24 ;-0.92)\end{array}$ & $\begin{array}{c}2.24 \\
(0.41 ; 4.06)\end{array}$ & $\begin{array}{c}1.57 \\
(0.62 ; 2.52)\end{array}$ \\
\hline & Trend AFP II & $\begin{array}{c}0.14 \\
(0.04 ; 0.24)\end{array}$ & $\begin{array}{c}-0.25 \\
(-0.33 ;-0.17)\end{array}$ & $\begin{array}{c}0.11 \\
(-0.02 ; 0.23)\end{array}$ & $\begin{array}{c}-0.01 \\
(-0.07 ; 0.06)\end{array}$ \\
\hline & $\begin{array}{l}\% \text { relative change } \\
\text { (May } 2010 \text { - AFP II) }\end{array}$ & -0.43 & -13.75 & 13.12 & 11.10 \\
\hline & Level in Jan-2011 & 23.58 & 30.83 & 32.27 & 8.97 \\
\hline \multirow[t]{3}{*}{$\begin{array}{l}\text { SNP } \\
\text { (February 2011) }\end{array}$} & $\begin{array}{l}\text { Level SNP } \\
\text { (Change at the intervention) }\end{array}$ & $\begin{array}{c}-0.84 \\
(-2.33 ; 0.64)\end{array}$ & $\begin{array}{c}-1.73 \\
(-2.95 ;-0.51)\end{array}$ & $\begin{array}{c}4.66 \\
(2.75 ; 6.57)\end{array}$ & $\begin{array}{c}-2.18 \\
(-3.17 ;-1.18)\end{array}$ \\
\hline & Trend SNP & $\begin{array}{c}-0.34 \\
(-0.44 ;-0.23)\end{array}$ & $\begin{array}{c}-0.06 \\
(-0.14 ; 0.03)\end{array}$ & $\begin{array}{c}0.3 \\
(0.18 ; 0.43)\end{array}$ & $\begin{array}{c}0.09 \\
(0.02 ; 0.16)\end{array}$ \\
\hline & $\begin{array}{l}\% \text { relative change } \\
\text { (March } 2012-\mathrm{SNP})\end{array}$ & -19.56 & -8.27 & 23.34 & -10.16 \\
\hline
\end{tabular}

AFP-I — expansion for private sector; AFP-II — reduction of reference prices and consequent increase patient copayment; SNP — all covered medicines for hypertension and diabetes being free of charge to patients.

$-7.14 \%,-7.12 \%$ for captopril, enalapril, losartan and MNC (Figure 2 and Table 1).

The AFP-II, which increased patient copayment, was associated with a reduction in the market share volumes for captopril and enalapril, medicines covered by FP at the time. Market shares increased for losartan and MNC in this period. By May 2010, there were relative changes of $-13.75 \%$, $13.12 \%$ and $11.10 \%$, respectively, for enalapril, losartan and MNC (Figure 2 and Table 1).

The SNP program implemented in February 2011, which eliminated patient copayments for covered medicines, had a great impact on the pharmaceutical market. Losartan, which was incorporated in the FP medicines list in March 2010 , experienced an increase of $23.34 \%$ in market share one year after the SNP. Market shares for captopril and enalapril decreased by $-19.56 \%$ and $-8.27 \%$, respectively, despite increases in sales volume. MNC experienced declining market share and slight reductions in sales volume (Figure 2 and Table 1).
Regarding affordability, one month's treatment with enalapril, the most used ACE, would cost 0.53 and 3.2 national minimum days' wage considering, respectively, FP reference price and maximum selling price, compared with 0.53 and 1.30 national minimum days' wage for losartan.

The profile of the top companies according to volume market share was different before AFPII when compared to sales market share. Generic producers (Medley, Neoquimica and EMS) accounted for more than $30 \%$ of the market for the entire period analyzed, excluding the baseline (Table 2) and ranked between first and fourth position. During AFP-I and AFP-II, the top five companies were national - Medley, EMS, NeoQuimica, Biolab, Ache - , of which the first three are generic producers.

National companies also experienced an increase in sales market share during the period analyzed, from $29.6 \%$ in the baseline period to $37.3 \%$ in the SNP period. After the SNP, Medley, Neoquimica and EMS held respectively the 
second, third and fourth place and accounted for more than 25\% of the Brazilian C09 market in sales (Table 2).

Novartis was in eight place in the period 2002 to 2004 , but by the end of the period analyzed, it occupied the first position, accounting for 15.8\% of the market volume, reflecting an impressive growth overtime. Novartis held the first position for the market share in sales from May 2004 to October 2013, accounting for about 25\% of the pharmaceutical market in the therapeutic class of interest. Although Astrazeneca is one of the top five in sales (local currency) for the period analyzed, it was not among the top five in volume, suggesting that the their products are being sold at higher prices (Table 2).

\section{Discussion}

The analysis covers the sales and volume of all products in the selected therapeutic class in retail private pharmacies in Brazil, including products covered by FP (captopril, enalapril and losartan

Table 2. Percentage distribution of market share of C09 Emphra class top companies in volume and sales. IMS Health data. Brazil, 2002 to 2013.

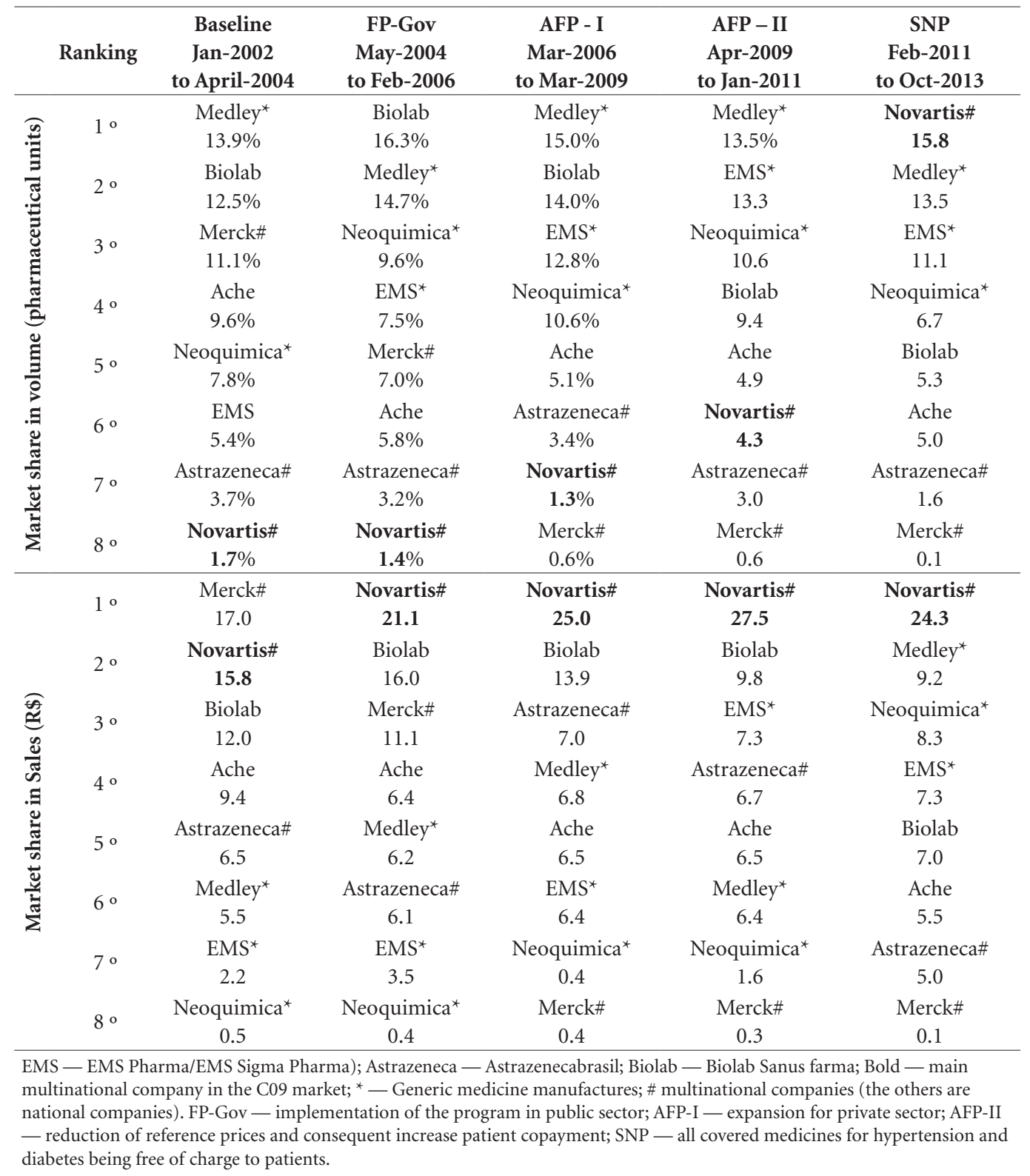


for C09 class) as well as those not covered by FP. Changes in FP policies were associated with changes in market share of the ACEs and ARB analyzed, with covered products demonstrating different trends from those not covered; these effects were quite different when considering sales and volume. There was an increase in the market share of national generic producers, especially in volume, while Norvatis showed a marked increase market share for its products.

The FP Program had a low impact in the general C09 market until 2006, probably because of the low number of government dispensing facilities before the program was expanded to include private pharmacies.

ARBs have been registered in Brazil since the end of 1990s and since the mid-2000's, there have been more than 15 producers of innovator products, branded generics, and non-branded generics. Despite that, ARBs only showed an important increase in market volume with the inclusion of Losartan in FP in 2010.

Losartan was included in RENAME, the Brazilian essential medicines list in 2008. At that time, it was recommended as a second option for patients intolerant of ACE inhibitors ${ }^{15}$. ARBs were regarded as beneficial to mortality and hospitalization outcomes for patients having heart failure. The most recent Brazilian official recommendations for antihypertensive treatment make no distinction in the indications for ACEs and $\mathrm{ARBs}^{16}$. The Brazilian Cardiologic Society notes the similar efficacy of ACEs and ARBs, but the better tolerability for the latter, with improved adherence. In its hypertension treatment guidelines, ARBs are indicated, especially for patients showing high cardiovascular risk or co-morbidities $^{17}$. Actually, the affordability is better to hypertension treatment with losartan, both to patients in out-of-pocket payment (maximum consumer price) as well as to the government (FP reference price).

All medicines analyzed showed very similar trends in volume until 2009 (AFP-II) with a notable difference from 2011 onwards, suggesting a strong influence of SNP in the general market. Costa et al. ${ }^{18}$ found that one-third of hypertensive patients obtained at least one medicines in $\mathrm{FP}$ in 2013. This implies that even a medicine included in FP may have been obtained under outof-pocket payment. Thus, our findings suggest an important effect of FP in the general market.

Others interventions and pharmaceutical policy reform (e.g. guidelines, patent expiries, reimbursement restrictions, budget devolution) can affect and change the volumes and expenditure of antihypertensive in other countries ${ }^{19,20}$. In United States of America, Medicare Part D was associated with increased use of antihypertensive and ARBs over less expensive alternatives, among seniors ${ }^{21}$.

The incorporation of losartan in the FP coincides with the increase of the market share volume of this medicine and the decrease of the market volume of ACE inhibitors and MNCs. The inclusion of losartan in FP reversed its prior negative trend, achieving an increase of $23.34 \%$ in March 2012. Considering these two sub-classes as therapeutic alternatives ${ }^{13}$, this suggests a shift in prescribing from ACE inhibitors to ARBs. Araújo et al. ${ }^{22}$, in a pre-post analysis of SNP also found an important increase in the consumption of losartan from 2010 to 2012. This study is consistent with our findings regarding the economic importance of losartan. The authors ${ }^{22}$ point out that, despite the late inclusion of losartan in FP in 2010, it represented the highest share of government expenditures in all AFP since its inclusion.

About generic medicines, the first register of generic versions of losartan occurred in 2002, in Brazil. New registries for generic versions were also documented in 2003 and 2004 (three per year). In 2005 and 2006 there were a gap in registries. In 2007 new registries occurred and more important, a greater number of new manufactures (Zydus, Teuto, EMS, EMS Sigma Pharma and Germed). From 2008 to 2012 it was a decline in the number of new registries to manufacture generic version of Losartan (average of 1,2 registers per year $)^{23}$. These points show the prior existence of generic medicines to the FP, reinforcing the influence of this Program in the Brazilian pharmaceutical market.

In relation to the ranking of the top eight companies market share volume and sales, results show that eight companies (Medley, Biolab, EMS, Neoquímica, Ache, Astrazeneca, Merck and Novartis) are the same for both, although they vary in the position. While Medley accounted for the highest market share volume during three periods, Novartis was the leader in sales during four periods.

An oligopoly market may be understood as one in which "a small number of big sellers share the market, in a way that they are able to recognize the interaction among their own behavior and the responsiveness of their rivals to define the market variables" ${ }^{24}$. We found that these eight leading companies were responsible for $65.7 \%$ of the C09 class market in the baseline period and 
$59.1 \%$ during the SNP period in terms of volume. In relation to sales, they accounted for $68.9 \%$ and $66.7 \%$, respectively, during the same periods, which characterizes an oligopoly market.

Reinforcing the interaction between FP and the market, Trevisan and Junqueira ${ }^{25}$ argue that the FP Program plays a role as part of the MoH's strategy to contain the pharmaceutical industry's commercial deficit by encouraging the link between national production of pharmaceuticals and the SUS network management. These authors argue that FP has led to an increase in medicines consumption among $\mathrm{C}$ and $\mathrm{D}$ social-economic classes, which can be related to the gross domestic product (GDP). According to them, this have reflected on job posts offer and increased income as well as increase in pharmacies and drugstores that target $\mathrm{C}$ socioeconomic class, consequently leading them to consuming other pharmaceuticals, mainly branded generics (called similares in Brazil).

In addition to the increased supply of generic products, one of the effects of the FP policy has been promotion of national companies. From August 2002 to August 2005, Medley, EMS Sigma Pharma, Biosintética and Eurofarma accounted for about $73 \%$ of the Brazilian market, sales of generic products ${ }^{26}$. This study shows similar results.

The enforcement of the generic policy, which has been in place since 1999, is one of the objectives of FP. The government has been implementing a series of strategies in this direction ${ }^{26}$, including industrial policy efforts. The changes in market share, both in sales and in volume, suggest that FP plays an important role in the generic market. A 2007 study which analysed the performance of the FP in the public and private sectors in terms of availability and cost of medicines for hypertension and diabetes found that generic medicines have achieved the highest percentage of availability in both sectors ${ }^{27}$.

One hypothesis to explain the similarity in rank of companies for both volume and sales is related to price paid. In AFP-I and AFP-II, the government paid $90 \%$ of the reference price, while patients paid $10 \%$ of the selling price, which could be lower or higher than the reference price. When the government started to pay $100 \%$ of the price under SNP, this brought all prices to the reference price.

Novartis increased sharply its participation after SNP, both in volume and sales. Until 2011 there was only one producer for valsartan (Diovan $^{\circledR}$ ), available as a single product as well as in a fixed dose combination with hydrochlorothiazide. According to Interfarma ${ }^{28}$ Diovan $^{\circledR}$ was among the most sold medicines in Brazil in the period of analysis (2007-2011), occupying the fifth position in 2010 and the fourth in 2011. Novartis kept its leadership in the C09 market share, despite entry to the market of two new producers of valsartan (EMS and Medley) in February 2011.

This paper used ITS for analysis, one of the strongest methods for public policy analysis. However, the paper also has some limitations. One is related to the classification of the database in relation to the combinations sub-classes. From 2002 to 2006, there was only one group called "Ant. Angiotensi.II, Assoc" but this was subdivided into two sub-classes from 2007 on "ANT ANGIOII ASS ANT/CALC" and "AT AGII ASS HIPC2 E/O DI". Therefore, the comparison was likely to be more accurate on sub-classes of single drugs. We considered all medicines registered in Brazil in 2013, but it is possible that there was variation in the times of their entry into the market during the study period. However, this is unlikely to have had any significant effect on our findings, given the size of the market share of medicines covered in FP in relation to those not covered. Manufacturer status as a generic (non-branded) producer considered the situation in August 2016, but this is unlike to have many variation along time. Because of the long study period, we were no able to map other market influence factors, such as changes in guidelines, approvals of other indications for the antihypertensive, patent expiries and introduction of new medicines. In addition, we did not take on consideration medicines prescribing or consumption profile in SUS, since there is no national information system in place.

\section{Conclusions}

Our data demonstrates the important effect of FP in the general pharmaceutical market. C09 medicines included in the FP reference list increased their share of the market, both in sales and volume, especially after the SNP free medicines program. Losartan became an affordable treatment, achieving a high market share. Also, its producer achieved the first place when ranking 09 companies, both in volume as well in sales. 


\section{Collaborations}

RM Silva, VL Luiza, GC Chaves, ICM Emmerick e MR Campos participaram da concepção e delineamento, montagem e análise do banco de dados e revisão do artigo. AD Bertoldi, LA Chaves e D Ross-Degnan contribuíram para o texto e a revisão final do artigo.

\section{References}

1. Sindicato da Indústria de Produtos Farmacêuticos no Estado de São Paulo (Sindusfarma). Indicadores econômicos [Internet]. 2015. [cited 2016 Jan 21]. Available at: http://sindusfarma.org.br/cadastro/index.php/site/ ap_indicadores

2. Instituto Brasileiro de Geografia e Estatística (IBGE). Conta-satélite de saúde: Brasil, 2010-2013. Rio de Janeiro: IBGE; 2015. (Contas nacionais).

3. Organization for Economic Co-operation and Development (OECD). Health at a Glance 2015 [Internet]. OECD Publishing; 2015. [cited 2017 Jan 2]. Available at: http://www.oecd-ilibrary.org/social-issues-migration-health/health-at-a-glance-2015_health_glance2015-en

4. Santos Pinto CDB. Copagamento como ampliação do acesso a medicamentos: Programa Farmácia Popular do Brasil. In: Osorio-de-Castro CGS, Luiza VL, Castilho SR, Oliveira MA, Marin N, organizadores. Assistência farmacêutica: gestão e prática para profissionais da saúde. Rio de Janeiro: Editora Fiocruz; 2014. p. 355362.

5. Machado CV, Baptista TWF, Nogueira CO. Políticas de saúde no Brasil nos anos 2000: a agenda federal de prioridades (Health policies in Brazil in the 2000s: the national priority agenda). Cad Saude Publica 2011; 27(3):521-532.

6. Silva RM, Caetano R. Costs of Public Pharmaceutical Services in Rio de Janeiro Compared to Farmácia Popular Program. Rev Saude Publica 2016; 50:74.

7. Mengue SS, Bertoldi AD, Ramos LR, Farias MR, Oliveira MA, Tavares NUL, Arrais PSD, Luiza VL, Pizzol TSD. Access to and use of high blood pressure medications in Brazil. Rev Saude Publica 2016; 50(Supl. 2):8s.

8. Schmidt MI, Duncan BB, Azevedo e Silva G, Menezes AM, Monteiro CA, Barreto SM, Chor D, Menezes PR. Chronic non-communicable diseases in Brazil: burden and current challenges. Lancet 2011; 377(9781):19491961.

9. Emmerick ICM, Luiza VL, Campos MR, Ross-Degnan D, Chaves LA, Bertoldi AD, Silva RM. Impact of consecutive subsidies policies on access to and use of medicines in Brazil - ISAUM-Br Final Report. Fundação Oswaldo Cruz; 2016.

10. Brasil. Ministério da Saúde (MS). Portaria n ${ }^{\circ}$. 111, de 28 de janeiro de 2016. Dispõe sobre o Programa Farmácia Popular do Brasil (PFPB). Diário Oficial da União 2016 ; 29 jan.

11. European Pharmaceutical Marketing Research Association EphMRA. EphMRA Anatomical Classification Guidelines 2013 final [Internet]. EphMRA; 2013. [cited 2016 Oct 21]. Available at: http://www.ephmra. org/user_uploads/ephmra\%20atc\%20guidelines $\% 20$ 2013\%20final.pdf

12. Jandoc R, Burden AM, Mamdani M, Lévesque LE, Cadarette SM. Interrupted time series analysis in drug utilization research is increasing: systematic review and recommendations. J Clin Epidemiol 2015; 68(8):950956.

13. Wagner AK, Soumerai SB, Zhang F, Ross-Degnan D. Segmented regression analysis of interrupted time series studies in medication use research. J Clin Pharm Ther 2002; 27(4):299-309. 
14. Kornis GEM, Braga MH, Paula PAB. Transformações recentes da indústria farmacêutica: um exame da experiência mundial e brasileira no século XXI. Physis 2014; 24(3):885-908.

15. Brasil. Ministério da Saúde (MS). Relação Nacional de Medicamentos Essenciais: Rename 2009. 6º ed. Brasília: MS; 2009.

16. Brasil. Ministério da Saúde (MS). Estratégias para o cuidado da pessoa com doença crônica: hipertensão arterial sistêmica. Brasília: MS; 2013. (Cadernos de Atenção Básica).

17. Poli-de-Figueiredo CE, Tavares A, Freitas EV, Burdmann E A, Oliveira ILC, Magalhães LC, Sass N, Bresolin NL, Bezerra R, Koch V, Fagundes VG. Hipertensão em situações especiais. J Bras Nefrol 2010; 32:54-59.

18. Costa KS, Tavares NUL, Mengue SS, Aurélio Pereira M, Malta DC, Silva Júnior JB. Obtenção de medicamentos para hipertensão e diabetes no Programa Farmácia Popular do Brasil: resultados da Pesquisa Nacional de Saúde, 2013. Epidemiol E Serviços Saúde 2016; 25(1):10-11.

19. Godman B, Bucsics A, Burkhardt T, Schmitzer M, Wettermark B, Wieninger P. Initiatives to enhance renin-angiotensin prescribing efficiency in Austria: impact and implications for other countries. Expert Rev Pharmacoecon Outcomes Res 2010; 10(2):199-207.

20. Huskamp HA, Epstein AM, Blumenthal D. The Impact Of A National Prescription Drug Formulary On Prices, Market Share, And Spending: Lessons For Medicare? Health Aff (Millwood) 2003; 22(3):149-158.

21. Zhang Y, Donohue JM, Lave JR, Gellad WF. The Impact of Medicare Part D on Medication Treatment of Hypertension: Impact of Part D on Antihypertensive Use. Health Serv Res 2011; 46(1p1):185-198.

22. Araújo JLO, Pereira MD, Sá Del Fiol F, Barberato-Filho S. Access to Antihypertensive Agents in Brazil: Evaluation of the "Health Has No Price" Program. Clin Ther 2014; 36(8):1191-1195.
23. Agência Nacional de Vigilância Sanitária. Medicamentos Genéricos Registrados (atualizada em 03/08/2016) [Internet]. [cited 2017 Jan 8]. Available at: http://portal.anvisa.gov.br/documents/33836/352400/Gen\%C3\%A9ricos+registrados+-+por+refer\%C3\%AAncia+29-02-2016.pdf/e1b3712f-5282-4e8c-b96d2da759708735

24. Cavalcanti RC. CADE: O oligopólio no Estado brasileiro de internvenção necessária [tese]. São Paulo: Pontífica Universidade Católica de São Paulo; 2014.

25. Trevisan L, Junqueira LAP. Gestão em rede do SUS e a nova política de produção de medicamentos. Saúde e Soc 2010; 19(3):638-652.

26. Quental C, Abreu JC, Bomtempo JV, Gadelha CAG. Medicamentos genéricos no Brasil: impactos das políticas públicas sobre a indústria nacional. Cien Saude Colet 2008; 13(Supl.):619-628.

27. Santos-Pinto CDB, Miranda ES, Martins IC, Emmerick, Costa NR, Osorio-de-Castro CGS. Preços e disponibilidade de medicamentos no Programa Farmácia Popular do Brasil. Rev Saude Publica 2010; 44(4):611-619.

28. Associação da Indústria Farmacêutica de Pesquisa. Guia Interfarma 2012 [Internet]. 2012 [cited 2016 Oct 23]. Available at: http://www.interfarma.org.br/uploads/biblioteca/16-Guia_Interfarma_2012_SITE.pdf

Artigo apresentado em 20/01/2017

Aprovado em 21/03/2017

Versão final apresentada em 22/03/2017 